\title{
Italian vs worldwide history of largest PGA and PGV
}

\author{
Akiko Suzuki, Iunio Iervolino \\ Dipartimento di Strutture per l'Ingegneria e l'Architettura, Università degli Studi di Napoli Federico II, Naples, Italy
}

\author{
Article history \\ Received February 21, 2017; accepted May 20, 2017. \\ Subject classification: \\ Ground motion, Seismic hazard, Earthquake intensity, Engineering seismology.
}

\begin{abstract}
Earthquake engineering and engineering seismology greatly rely on the information gathered from observed data. This is especially true when it comes to ground motion intensity measures, which are related to the damaging potential of earthquakes. Observed maxima of peak ground acceleration (PGA) and peak ground velocity (PGV) can provide reference values for hazard assessment, which often needs to extrapolate towards large return periods. This simple study attempts to reconstruct the history of the largest values of PGA and PGV observed in Italy since 1972. Results reveal that the current maxima of $P G A$ and $P G V$ were recorded during the 2016 central Italy earthquake sequence. For comparison, up-to-date global trends of PGA and PGV maxima are also compiled, following relevant literature on the topic and investigating a number of international databases. It is found that these trends, which are roughly linear in logarithmic scale, correspond to the increase of ground motion records worldwide.
\end{abstract}

\section{Introduction}

According to the ITalian ACcelerometric Archive (ITACA), the history of Italian strong motion earthquake recordings dates back to 1972 . Since then, infrastructures for seismic strong motion recording have been continuously developing, responding to the needs of earthquake-related research and seismic hazard evaluations. The recordings are mainly acquired by the Italian accelerometric network (Rete Accelerometrica Nazionale, RAN) operated by the Italian Civil Protection Department (DPC) and the national seismic network operated by Istituto Nazionale di Geofisica e Vulcanologia (INGV). Because of evolution of these monitoring networks and the shift from analog to digital recordings, availability of high-quality earthquake data rapidly evolved in the last decades.

ITACA, started in 2006, archives those ground motion recordings acquired by different institutions in a unified data format [Luzi et al. 2016a]. The data-set of ITACA contains more than thirty-thousand three-component waveforms from earthquakes with maximum moment magnitude ( $\mathrm{Mw}$ ) equal to 6.9.

As data increase, it is expected (and actually observed) that the largest recorded value of a ground motion intensity measure (IM) tends also to increase over time. This shall occur even if it is postulated that the seismicity shows some stationarity (as it is typically assumed in hazard studies). In fact, the expected value of the maximum in a sample of size $n$ (i.e., obtained from $n$ independent and identically distributed random variables, RVs) increases as $n$ increases. If the RV is the IM in a generic earthquake, then the growth of strong motion databases and/or data from longer observation periods are analogous to enlarge the sample size. The larger the sample the more likely the tail of the distribution is sampled.

The trend of the maximum recorded values of ground motion IMs has been studied somewhat extensively. Bommer and Martínez-Pereira [2000] compiled the history of maximum peak ground acceleration (PGA) and peak ground velocity (PGV), in terms of horizontal and vertical components, recorded worldwide until 1999. That study was extended and updated later by Strasser and Bommer [2009a,b], S\&B hereafter, with a particular interest in causative physical process of large-amplitude ground motions. Çelebi et al. [2000] also showed that the maximum PGA had been increasing with the increase of the recorded strongground-motions, using North American records. Yamada et al. [2009] provided an update until 2009, including Japanese records the largest of which is the 2008 Iwate-Miyagi (Japan) earthquake. Following this relevant literature, this short study attempts to reconstruct the Italian history of the maximum recorded IMs and compares it with the worldwide trend, which was updated to 2016, investigating the ITACA database and several reputed regional or international seismic 
data repositories.

The remainder of the paper is structured as follows: the next section describes the investigated databases and the methodology to identify national and worldwide strong motion records with largest seismic intensities in the year of recording. Subsequently, the obtained histories are presented and discussed for PGA and PGV, in terms of both horizontal and vertical components, also linking with data increase per year. Final remarks close the study.

\section{Methodology}

To compile the Italian histories of maximum recorded PGA and PGV, a flat-file of the ITACA database was obtained (dr. Lucia Luzi, personal communication). All the processed (both automatically and manually) records in the flat-file, for which PGA and PGV were available, were sorted in terms of recording year. Then, the maximum IM, for each specific year, was determined for horizontal (the largest value between the two as-recorded components was considered) and vertical ground motions. Data are those collected until November 2016.

For comparison, also the worldwide histories of the largest PGA and PGV were updated after the latest relevant studies. In fact, for consistency, herein the worldwide histories were entirely recompiled. To this aim, a number of databases, defined as global or regional depending on the geographic origin of data, was considered. Among global databases those investigated are: the PEER Ground Motion Database NGA West 2 [PEER, Ancheta et al. 2014], the COSMOS Virtual Data Center [Archuleta et al. 2005], the Engineering Strong-Motion Database [ESM, Luzi et al. 2016b], ${ }^{1}$ the Selected Input Motion for displacement-Based Assessment and Design [SIMBAD, Smerzini and Paolucci 2013, Smerzini et al. 2014], and the Earthquake Strong

\footnotetext{
1 The latest updates in ESM were also tracked to account for the strong motion records from the 2016 central Italy earthquake sequence.

${ }^{2} \mathrm{~A}$ number of databases was also considered and then disregarded because of overlapping with the investigated repositories. This is the case of: the European Strong-Motion Database (ESMD; Ambraseys et al. 2004), Center for Engineering Strong Motion Data (CESMD; Haddadi et al. 2008), Iran Strong Motion Network (ISMN; Iran, Alavijeh et al. 2003), National Strong-Motion Network of Turkey (Turkey, http:/ / kyhdata.deprem.gov.tr/), and Swiss Seismological Service (SED, Switzerland; Fäh et al. 2011). For other databases, data retrieval or format issues also prevented further investigation. They are: Incorporated Research Institutions for Seismology database (IRIS; https://www.iris.edu/), Canadian National Seismograph Network (CNSN, Canada; North et al. 1994), NORwegian Seismic ARray (NORSAR, Norway; Bungum et al. 1971), and Central Weather Bureau (CWB, Taiwan; http:/ / www.cwb.gov.tw/).
}

Motion Data catalog provided by the National Oceanic and Atmospheric Administration (NOAA). Among regional databases: the K-NET\&KiK-net seismic networks of the Japanese National research Institute for Earth science and Disaster resilience [NIED, Aoi et al. 2004], as wells as that of the Japan Meteorological Agency (JMA) and of the Port and Airport Research Institute (PARI), the New Zealand Strong-Motion Database [GeoNet, Van Houtte et al. 2017, Kaiser et al. 2017], the Chile Strong Ground Motion Flatfile [CSGMF, Bastías and Montalva 2016], the Mexican Strong Motion Database [MSMD, Quaas et al. 1996, Alcántara et al. 2000, Alcántara and Pérez 2004], released as a CD-ROM (prof. Eden Bojorquéz, personal communication), and the database from Red Acelerográfica del IINGEN de la UNAM, still from Mexico. ${ }^{2}$ These data-sources were investigated in one of the following ways depending on the available information.

(1) As for ITACA, the databases directly providing the flat-files with metadata (i.e., PEER, SIMBAD, GeoNet, and CSGMF) were sorted in terms of recording year, then the annual maxima, in terms of the considered IMs, were taken for horizontal and vertical components separately. Note that in PEER, the intensity values are listed in the horizontal orientation-independent scale, RotD50 [Boore et al. 2010]. In this case, the values of RotD50 were ranked first. Then, only for those top-ranking, the two horizontal IM values were retrieved from the corrected waveforms. To complement potential omissions, the horizontal IM values of some record-breaking ground motions specified in other databases were also individually examined. With regard to the vertical components, the PEER database was only used to check top-ranking IM values from other databases.

(2) For the databases providing search engines either online or via CD-ROM (i.e., COSMOS, ESM, NOAA, K-NET\&KiK-net, PARI, MSMD, and UNAM), the maximum intensity histories were obtained identifying the recordings with the peak IM value year-by-year, with the aid of parameter-entry search functions. In the case of search engines filtering the records by the vector-sum or the largest value IM among the three components, a three-step search was performed: (i) the records were ranked in terms of the IM used by the search engine; (ii) only for some top-ranking, the peak intensity values of 
each component (two horizontal and vertical) were retrieved using the original waveforms; (iii) the component values were used, in turn, to search again the database for recordings with larger IM, when the latter is the one considered by the search engine. This procedure was carried out for the horizontal and vertical components separately.

(3) The JMA database provides only records from some large Japanese earthquakes since the last decades. In this case, all were accessed as well as relevant related literature.

The largest intensity value was considered in case of overlapping records among different databases.

It is to note that some of the search procedures employed in this study, which has a modest scope with respect to previous literature (i.e., only comparison with Italian trend), are simplified and may lead to miss some peak IMs. Moreover, while S\&B [2009a,b] generally considered uncorrected records, herein waveforms are mostly corrected (Japanese and Mexican records are an exception). Also, the strong motion data sources covered in this study are not exactly the same as S\&B [2009a,b]. Thus, the generality of the results may be limited.

\section{Italian trend}

Table 1 and Table 2 chronologically show the ground motion records with the largest IMs retrieved as discussed in the previous section, and provide the basic ground motion parameters (the soil classification in the list is based on Eurocode 8 or EC8, CEN 2003). As it regards PGA (Table 1), the first available recorded values are from 1972. The maximum PGA for that year is from the Ancona earthquake (local magnitude, $\left.M_{L}, 4.7\right), 0.56 \mathrm{~g}$ horizontal and $0.28 \mathrm{~g}$ vertical, at the Ancona Rocca station. Four years later, these values were exceeded by an aftershock of the Friuli earthquake on September 151976 (Mw 5.9), with 0.64g horizontal and $0.49 \mathrm{~g}$ vertical, at the Gemona station. The horizontal maximum was surpassed more than thirty years later by an aftershock of L'Aquila earthquake on April 72009 (Mw 5.5) at the Sant'Eusanio Forconese station: $0.66 \mathrm{~g}$. It was further updated to $0.87 \mathrm{~g}$ by the Amatrice earthquake ( $\mathrm{Mw} 6.0$ ), that is the event initiating the 2016 central Italy seismic sequence. ${ }^{3}$ Interestingly, it seems that, after the 1976 Friuli earthquake, the ver-

\footnotetext{
${ }^{3}$ At the time of writing the sequence is still ongoing. Moreover, some near-source data show larger recorded PGAs (i.e., around $1 \mathrm{~g}$ ), but at this time are not considered fully reliable by the RAN managers. Therefore, they are not included herein; see ReLUIS-INGV Workgroup (2016) for information.
}

tical maximum was exceeded by a small-magnitude event (Mw 4.3) in the 1997 Umbria/Marche sequence at the Casermette station, with $0.73 \mathrm{~g}$. The 2012 Emilia earthquake ( $\mathrm{Mw}$ 6.0) increased the vertical maximum PGA to $0.86 \mathrm{~g}$, followed by the Norcia earthquake on October 302016 (Mw 6.5) with 0.89g at the Savelli PG station. From this analysis, it is concluded that the maximum PGA values in Italy increased by approximately $54 \%$ and $220 \%$ in horizontal and vertical components, respectively, in the last forty-five years.

Regarding the Italian largest PGV history, the lineup in Table 2 is similar to PGA, except that no records from the 2009 L'Aquila or the 1997 Umbria/Marche sequences appear; in turn, the 1980 Irpinia earthquake (Mw 6.9) scores for both horizontal and vertical PGVs at the Sturno station. Again, the 2016 central Italy seismic sequence, the event on October $30(\mathrm{Mw}$ 6.5) in particular, holds the current maxima for horizontal and vertical components, $0.8 \mathrm{~m} / \mathrm{s}$ at the Amatrice (T1201, Domo RI) station and $0.7 \mathrm{~m} / \mathrm{s}$ at the Castelluccio di Norcia station, respectively.

\section{Worldwide trend}

\subsection{PGA}

Figure 1a,c shows the global trend of the maximum recorded PGA history for horizontal and vertical components, up to the end of 2016. As already shown in literature, the retrieved maximum PGA history starts with the 1933 Long Beach earthquake (at Public Utilities Building, California, 0.2g and 0.3g for horizontal and vertical, respectively) and terminates with the 2008 Iwate-Miyagi earthquake, Japan $(2.5 \mathrm{~g}$ at the Higashinaruse AKTH04 station, for horizontal; $3.9 \mathrm{~g}$ at the Ichinoseki IWTH25 station, for vertical). The present study revealed that, since then, the recordings from the 2011 Tohoku (Japan) earthquake led to update the previous maximum PGA for the horizontal component to $2.8 \mathrm{~g}$ (at the Tsukidate MYG004 station). It is worth to note, however, that the peculiarity of the Tsukidate record has been discussed by a number of researchers [e.g., De Luca et al. 2011, Goto and Morikawa 2012, Nagashima et al. 2012 and Motosaka 2012].

The compiled history up to 2008 is mostly consistent with S\&B [2009a,b]. Nevertheless, there are a few exceptions. Some earthquakes from the aforementioned studies did not show up in this investigation and vice-versa (Figure 1a). It is believed that this is mainly due to processing of waveforms. In particular, for the horizontal component, the maximum PGA value from the 1984 Morgan Hills earthquake (corrected: 


\begin{tabular}{|c|c|c|c|c|c|c|c|}
\hline Year & $\begin{array}{c}\text { Event } \\
\text { (Event id) }\end{array}$ & $\begin{array}{c}\text { Station } \\
\left(\text { Station code, Soil class }{ }^{\dagger}\right) \\
\end{array}$ & $\begin{array}{c}\text { Focal } \\
\text { Mechanism }\end{array}$ & $\begin{array}{c}\text { Magnitude } \\
\operatorname{Mw}\left(M_{L}\right)\end{array}$ & $\begin{array}{c}\text { Distance }^{* 1} \\
{[\mathrm{~km}]}\end{array}$ & $\begin{array}{c}\text { PGA } \\
{[\mathrm{g}]}\end{array}$ & Source \\
\hline \multicolumn{8}{|c|}{ Horizontal } \\
\hline 1972 & $\begin{array}{c}\text { Ancona } \\
(\text { IT-1972-0005) }\end{array}$ & $\begin{array}{l}\text { Ancona, Rocca } \\
\quad(\text { ANR, B) }\end{array}$ & Unknown & $(4.7)$ & 7.7 & 0.56 & {$[\mathrm{I}]$} \\
\hline 1976 & $\begin{array}{l}\text { Friuli aftershock } \\
\text { (IT-1976-0027) }\end{array}$ & Gemona (GMN, B) & Thrust & 5.9 & 6.2 & 0.64 & {$[\mathrm{I}]$} \\
\hline 2009 & $\begin{array}{l}\text { L'Aquila aftershock } \\
\text { (IT-2009-0102) }\end{array}$ & $\begin{array}{l}\text { Sant'Eusanio Forconese } \\
\left(\mathrm{MI05}, \mathrm{A}^{*}\right)\end{array}$ & Normal & 5.5 & 3.6 & 0.66 & {$[\mathrm{I}]$} \\
\hline 2016 & $\begin{array}{c}\text { Central Italy Aug. } \\
\text { (EMSC-2016082 } \\
\text { 4_0000006) }\end{array}$ & Amatrice (AMT, $\mathrm{B}^{*}$ ) & Normal & 6.0 & 8.5 & 0.87 & {$[\mathrm{I}]$} \\
\hline \multicolumn{8}{|c|}{ Vertical } \\
\hline 1972 & $\begin{array}{c}\text { Ancona } \\
\text { (IT-1972-0005) }\end{array}$ & $\begin{array}{c}\text { Ancona, Rocca } \\
\text { (ANR, B) }\end{array}$ & Unknown & $(4.7)$ & 7.7 & 0.28 & {$[\mathrm{I}]$} \\
\hline 1976 & $\begin{array}{c}\text { Friuli aftershock } \\
\text { (IT-1976-0027) }\end{array}$ & Gemona (GMN, B) & Thrust & 5.9 & 6.2 & 0.49 & {$[\mathrm{I}]$} \\
\hline 1997 & $\begin{array}{l}\text { Umbria/Marche } \\
\text { (IT-1997-0147) }\end{array}$ & $\begin{array}{l}\text { Colfiorito Casermette } \\
\qquad\left(\mathrm{CLC}, \mathrm{C}^{*}\right)\end{array}$ & Strike-slip & 4.3 & 1.3 & 0.73 & {$[\mathrm{I}]$} \\
\hline 2012 & $\begin{array}{c}\text { Emilia } \\
(\text { IT-2012-0011) }\end{array}$ & Mirandola (MRN, C) & Thrust & 6.0 & 4.1 & 0.86 & {$[\mathrm{I}]$} \\
\hline 2016 & $\begin{array}{l}\text { Central Italy Oct. } \\
\text { (EMSC-20161030_- } \\
\text { 0000029) }\end{array}$ & Savelli PG (T1213, A*) & Normal & 6.5 & 12.0 & 0.89 & {$[E]$} \\
\hline
\end{tabular}

Table 1. Italian ground motion records with largest recorded PGA. $\left({ }^{\dagger} \mathrm{EC} 8\right.$ classification [CEN 2003], ${ }^{*}$ not based on a direct shear-wave velocity in the upper $30 \mathrm{~m}$ measurement, ${ }^{*}$ Epicentral distance, $\left.[\mathrm{I}]=\mathrm{ITACA},[\mathrm{E}]=\mathrm{ESM}\right)$.

\begin{tabular}{|c|c|c|c|c|c|c|c|}
\hline Year & $\begin{array}{c}\text { Event } \\
\text { (Event id) }\end{array}$ & $\begin{array}{c}\text { Station } \\
\left(\text { Station code, Soil class }{ }^{\dagger}\right)\end{array}$ & $\begin{array}{c}\text { Focal } \\
\text { Mechanism }\end{array}$ & $\begin{array}{c}\text { Magnitude } \\
\operatorname{Mw}\left(M_{L}\right)\end{array}$ & $\begin{array}{c}\text { Distance }^{* 1} \\
{[\mathrm{~km}]}\end{array}$ & $\begin{array}{c}\mathrm{PGV} \\
{[\mathrm{cm} / \mathrm{s}]}\end{array}$ & Source \\
\hline \multicolumn{8}{|c|}{ Horizontal } \\
\hline 1972 & $\begin{array}{c}\text { Ancona } \\
\text { (IT-1972-0007) }\end{array}$ & $\begin{array}{c}\text { Ancona, Rocca } \\
(\text { ANR, B) }\end{array}$ & Unknown & $(4.2)$ & 9.3 & 12.1 & {$[\mathrm{I}]$} \\
\hline 1976 & $\begin{array}{l}\text { Friuli aftershock } \\
\text { (IT-1976-0027) }\end{array}$ & Gemona (GMN, B) & Thrust & 5.9 & 6.2 & 68.4 & {$[\mathrm{I}]$} \\
\hline 1980 & $\begin{array}{c}\text { Irpinia } \\
\text { (IT-1980-0012) }\end{array}$ & Struno (STR, B) & Normal & 6.9 & 33.3 & 70.3 & {$[\mathrm{I}]$} \\
\hline 2016 & $\begin{array}{l}\text { Central Italy Oct. } \\
\text { (EMSC- } \\
\text { 20161030_0000029) }\end{array}$ & $\begin{array}{l}\text { Amatrice, Domo } \\
(\text { T1201, B*) }\end{array}$ & Normal & 6.5 & 23.3 & 83.0 & {$[E]$} \\
\hline \multicolumn{8}{|c|}{ Vertical } \\
\hline 1972 & $\begin{array}{c}\text { Ancona } \\
\text { (IT-1972-0005) }\end{array}$ & $\begin{array}{c}\text { Ancona, Rocca } \\
\text { (ANR, B) }\end{array}$ & Unknown & $(4.7)$ & 7.7 & 3.8 & {$[\mathrm{I}]$} \\
\hline 1976 & $\begin{array}{c}\text { Friuli aftershock } \\
\text { (IT-1976-0027) }\end{array}$ & Gemona (GMN, B) & Thrust & 5.9 & 6.2 & 20.6 & {$[\mathrm{I}]$} \\
\hline 1980 & $\begin{array}{c}\text { Irpinia } \\
(\text { IT-1980-0012) }\end{array}$ & Struno (STR, B) & Normal & 6.9 & 33.3 & 23.3 & {$[\mathrm{I}]$} \\
\hline 2012 & $\begin{array}{c}\text { Emilia } \\
(\text { IT-2012-0011) }\end{array}$ & Mirandola (MRN, C) & Thrust & 6.0 & 4.1 & 26.4 & {$[\mathrm{I}]$} \\
\hline 2016 & $\begin{array}{c}\text { Central Italy Oct. } \\
\text { (EMSC-20161030_ } \\
\text { 0000029) }\end{array}$ & $\begin{array}{l}\text { Castelluccio di Norcia } \\
\quad\left(\text { CLO }, A^{*}\right)\end{array}$ & Normal & 6.5 & 7.8 & 68.6 & {$[\mathrm{E}]$} \\
\hline
\end{tabular}

Table 2. Italian ground motion records with largest recorded PGV. (†EC8 classification [CEN 2003], ${ }^{*}$ not based on a direct shear-wave velocity in the upper $30 \mathrm{~m}$ measurement, ${ }^{*}{ }^{2}$ Epicentral distance, $\left.[\mathrm{I}]=\mathrm{ITACA},[\mathrm{E}]=\mathrm{ESM}\right)$.

$1.2 \mathrm{~g}$ at Coyote Lake Dam, San Martin, in NOAA, $1.16 \mathrm{~g}$ in COSMOS; uncorrected: 1.3g, Shakal et al. 1984) does not appear in this study because of the larger value from the 1971 San Fernando earthquake (1.24g at Pacoima dam in PEER, 1.17g in COSMOS). Conversely, the 1994 Northridge earthquake (corrected: $1.78 \mathrm{~g}$ at the Tarzana 
(a)

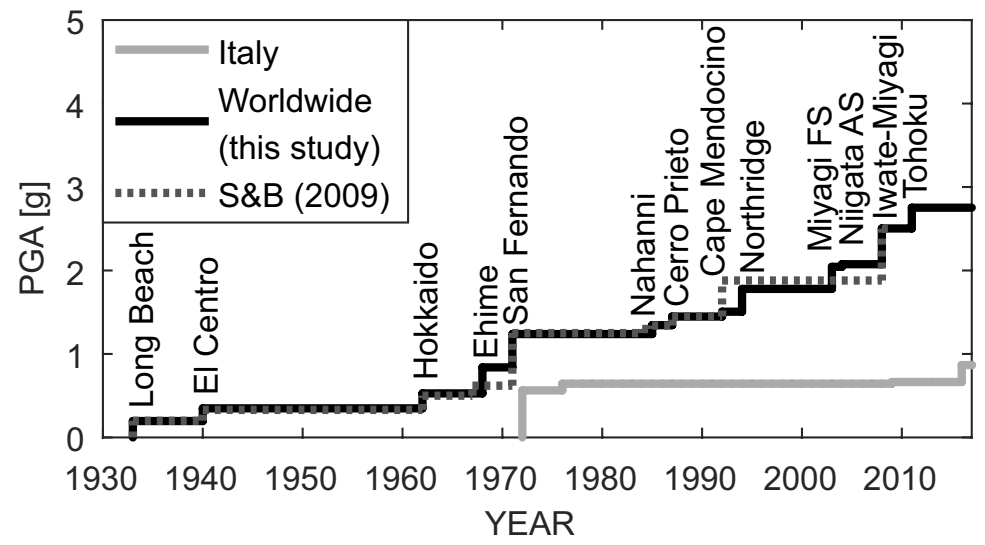

(c)

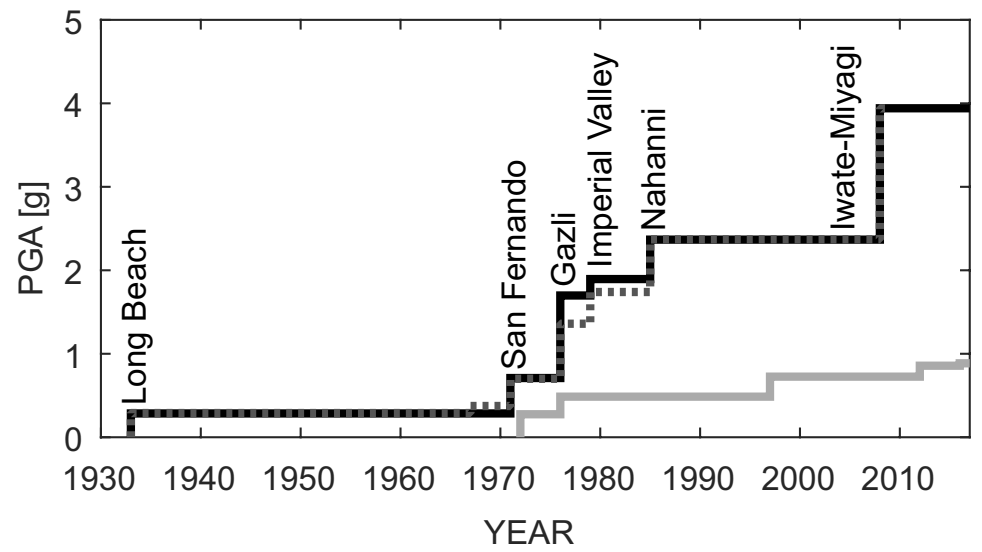

(b)

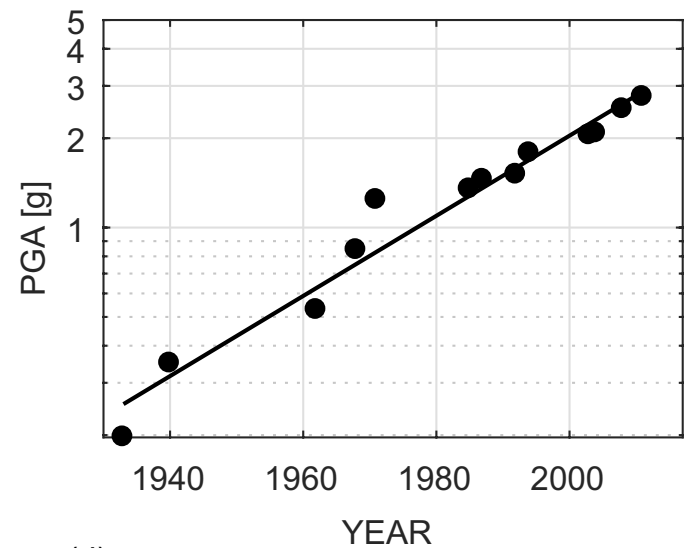

(d)

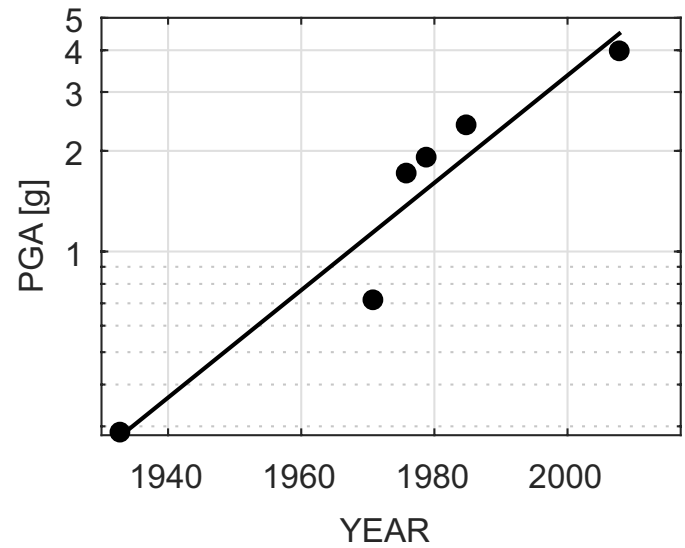

Figure 1. Largest recorded values of PGA, (a) horizontal; (b) worldwide horizontal in logarithmic scale; (c) vertical; (d) worldwide vertical in logarithmic scale.

station, California, from PEER) is not in the envelope of the horizontal PGA values in the cited studies because of the larger uncorrected value from the 1992 Cape Mendocino earthquake (corrected: $1.50 \mathrm{~g}$ at Cape Mendocino, California, in COSMOS; uncorrected: $1.88 \mathrm{~g}$, Darragh et al. 1992). S\&B [2009a,b] also did not include the record from the 1968 Ehime earthquake, Japan (0.84g at Itashima bridge from NOAA). For the vertical component (Figure 1c), the trends are similar between two studies, there are a few discrepancies in the PGA values though.

It is also worth to mention that this study verified via literature some large PGA values of Japanese earthquakes. This is the case of the JMA Kushiro record from the 1962 Hokkaido (Hiroo), for which information in Dan (1995) was considered more reliable than that from NOAA. Moreover, the largest PGA values from the Japanese earthquakes during 2003-2004 were acquired by local seismic networks, and related information is restricted [Japan Society of Civil Engineering and Japanese Geotechnical Society, JSCE and JGS 2003 and JMA 2004]. In fact, the waveform at the Naruse town office in the 2003 Northern Miyagi foreshock (FS) was lost during the aftershock sequence (as well as other records at different stations of the network, JSCE and
JGS, 2003), while that at the Kawaguchi station from the 2004 Niigata aftershock (AS), was not made available to the authors by JMA. It is also to note that the envelope of S\&B [2009a,b] excludes these records.

For more detailed information of the discussed ground motions, see Table 3 (the soil classification in the list is based on NEHRP soil classification - BSSC, 1994 mostly extracted from the PEER flat-file).

\subsection{PGV}

The global maximum PGV histories of horizontal and vertical components were also examined and the results are presented in Figure 2a,c. It is to note, however, that it was less straightforward to reconstruct the history for maximum PGV rather than for maximum PGA. This is because PGV values for the same records were found to be different among databases, likely because PGV is more sensitive to processing. It is also to mention that PGVs are not provided by all examined databases. For the former case, the discrepancies were solved considering the largest PGV values among those available. The latter case corresponds to the Japanese and Mexican repositories for which PGV is not provided. Therefore, the investigation was limited to some accelero- 


\begin{tabular}{|c|c|c|c|c|c|c|c|}
\hline Year & Event & $\begin{array}{c}\text { Station } \\
\left(\text { Soil class }^{\dagger}\right) \\
\end{array}$ & $\begin{array}{c}\text { Focal } \\
\text { Mechanism }\end{array}$ & $\begin{array}{c}\text { Magnitude } \\
\operatorname{Mw}\left(M_{L}\right)\end{array}$ & $\begin{array}{c}\text { Distance }^{* 1} \\
{[\mathrm{~km}]}\end{array}$ & $\begin{array}{c}\text { PGA } \\
{[\mathrm{g}]}\end{array}$ & Source \\
\hline \multicolumn{8}{|c|}{ Horizontal } \\
\hline 1933 & Long Beach & Public Utilities Bldg., CA (-) & Strike-slip & 6.4 & 0.8 & 0.20 & {$[\mathrm{C}]$} \\
\hline 1940 & El Centro & El Centro, Array \#9, CA (D) & Strike-slip & 6.9 & $12.2^{* 3}$ & 0.35 & {$[\mathrm{C}]$} \\
\hline 1962 & $\begin{array}{l}\text { Hokkaido } \\
\text { (Hiroo) }\end{array}$ & JMA Kushiro, Japan (-) & $\mathrm{N} / \mathrm{A}$ & $7.1^{\ddagger 1}$ & $92^{*_{2}}$ & 0.53 & {$[\mathrm{~N}]$} \\
\hline 1968 & Ehime & Itashima bridge, Japan (-) & $\mathrm{N} / \mathrm{A}$ & $6.6^{\ddagger 1}$ & $19^{* 2}$ & 0.84 & {$[\mathrm{~N}]$} \\
\hline 1971 & San Fernando & Pacoima Dam, CA (A) & Thrust & 6.6 & 1.8 & 1.24 & {$[\mathrm{P}]$} \\
\hline 1985 & Nahanni & $\begin{array}{l}\text { NWT -Station\#1, } \\
\text { Canada }(\mathrm{C})\end{array}$ & Thrust & $6.9^{\ddagger 2}$ & $*_{4}$ & 1.34 & {$[\mathrm{C}]$} \\
\hline 1987 & Cerro Prieto & $\begin{array}{l}\text { Cerro Prieto volcano, } \\
\text { Mexico (-, Rock) }\end{array}$ & Transform & (5.4) & $5.6^{* 2_{5}}$ & 1.45 & {$[\mathrm{M}]$} \\
\hline 1992 & Cape Mendocino & Cape Mendocino, CA (C) & Thrust & 7.0 & $15.5^{* 3}$ & 1.50 & {$[\mathrm{C}]$} \\
\hline 1994 & Northridge & $\begin{array}{l}\text { Tarzana, Cedar Hill } \\
\text { Nursery A, CA (D) }\end{array}$ & Thrust & 6.7 & 15.6 & 1.78 & {$[\mathrm{P}]$} \\
\hline 2003 & $\begin{array}{l}\text { Northern Miyagi } \\
\text { FS }\end{array}$ & $\begin{array}{c}\text { Naruse town office, } \\
\text { Japan (-) }\end{array}$ & Thrust & $5.6^{\ddagger 1}$ & $3.5^{* 3}$ & 2.04 & [J1] \\
\hline 2004 & Niigata AS & $\begin{array}{c}\text { Kawaguchi town office, } \\
\text { Japan (-) }\end{array}$ & Thrust & $6.5^{\ddagger 1}$ & $7.3^{* 3}$ & 2.08 & [J2] \\
\hline 2008 & Iwate-Miyagi & Higashinaruse, Japan (C) & Thrust & 6.9 & $22.6^{* 3}$ & 2.50 & {$[\mathrm{C}]$} \\
\hline 2011 & Tohoku & Tsukidate, Japan (C) & Megathrust & 9.0 & $131.0^{* 3}$ & 2.75 & {$[\mathrm{C}]$} \\
\hline \multicolumn{8}{|c|}{ Vertical } \\
\hline 1933 & Long Beach & Public Utilities Bldg., CA (-) & Strike-slip & 6.4 & 0.8 & 0.29 & {$[\mathrm{C}]$} \\
\hline 1971 & San Fernando & Pacoima Dam, CA (A) & Thrust & 6.6 & 3.5 & 0.71 & {$[\mathrm{C}]$} \\
\hline 1976 & Gazli & Karakyr, Uzbekistan (D) & Thrust & 6.8 & 5.5 & 1.70 & {$[\mathrm{P}]$} \\
\hline 1979 & Imperial Valley & $\begin{array}{c}\text { El Centro CA Array \#6, } \\
\text { CA (D) }\end{array}$ & Strike-slip & 6.5 & 1.4 & 1.89 & {$[\mathrm{P}]$} \\
\hline 1985 & Nahanni & $\begin{array}{l}\text { NWT -Station\#1, } \\
\text { Canada }(\mathrm{C})\end{array}$ & Thrust & $6.9^{\ddagger 2}$ & $*_{4}$ & 2.37 & {$[\mathrm{C}]$} \\
\hline 2008 & Iwate-Miyagi & Ichinoseki west, Japan (C) & Megathrust & 6.9 & $8.3^{* 3}$ & 3.94 & {$[\mathrm{C}]$} \\
\hline
\end{tabular}

Table 3. Records determining the compiled PGA history worldwide.

$\dagger$ NEHRP soil classification [BSSC 1994], (-) denotes unknown soil conditions.

$¥ 1$ JMA magnitude after the revision in 2004, http:/ / www.jma.go.jp/, $\$ 2$ Surface-wave magnitude, $\mathrm{M}_{\mathrm{S}}$.

${ }^{*}$ Closest distance ${ }^{{ }_{2}}$ Epicentral distance, ${ }^{*}$ Hypocentral distance, ${ }^{*}{ }_{4}$ Unknown, ${ }^{*}$ Munguia et al. [1988].

$[\mathrm{C}]=$ COSMOS, $[\mathrm{N}]=$ NOAA, $[\mathrm{P}]=$ PEER NGA, $[\mathrm{M}]=$ MSMD.

[J1] = JSCE and JGS [2003], [J2] = JMA [2004].

grams from the seismic events with the largest PGAs and some famous large earthquakes. For those records, the PGV values were computed from the corrected accelerograms (linear base correction and forth-order Butterworth filter between $0.10 \mathrm{~Hz}$ and $25 \mathrm{~Hz}$ ).

The reconstructed horizontal history is composed by the following records: the 1933 Long Beach, California $(0.29 \mathrm{~m} / \mathrm{s}$ at Public Utilities Building), the 1940 El Centro, California $(0.37 \mathrm{~m} / \mathrm{s}$ at Array \#9), the 1966 Parkfield, California $(0.78 \mathrm{~m} / \mathrm{s}$ at Cholame 2WA), the 1971 San Fernando, California $(1.14 \mathrm{~m} / \mathrm{s}$ at Pacoima dam), the 1978 Tabas $(1.23 \mathrm{~m} / \mathrm{s}$, at Tabas, Iran), the 1992 Cape Mendocino $(1.26 \mathrm{~m} / \mathrm{s}$ at Cape Mendocino, California), the 1994 Northridge, California $(1.48 \mathrm{~m} / \mathrm{s}$ at the Rinaldi receiving station), and the 1999 Chi-Chi earthquakes, Taiwan $(2.6 \mathrm{~m} / \mathrm{s}$ at Taichung, TCU068).
S\&B [2009a,b] created a single envelope for PGV, while this study accounted for the horizontal and vertical components separately. Nevertheless, the updated horizontal PGV history has some agreement with prior studies. Exceptions are PGV values from rotated waveforms (e.g., for the 1979 Imperial Valley, California, the 1987 Superstition Hill, California, and the 1994 Northridge, California, earthquakes) and processing (e.g., the 1992 Landers, California, Iwan and Chen [1995], the 1999 Chi-Chi, Taiwan, earthquake, Wang et. al. [2002]).

Compared to the horizontal envelope, relatively smaller increase in the vertical PGVs was observed over the years. The record-breaking events in vertical component are: the 1933 Long Beach, California $(0.31 \mathrm{~m} / \mathrm{s}$ at Public Utilities Building), the 1971 San Fernando, 
(a)



(c)

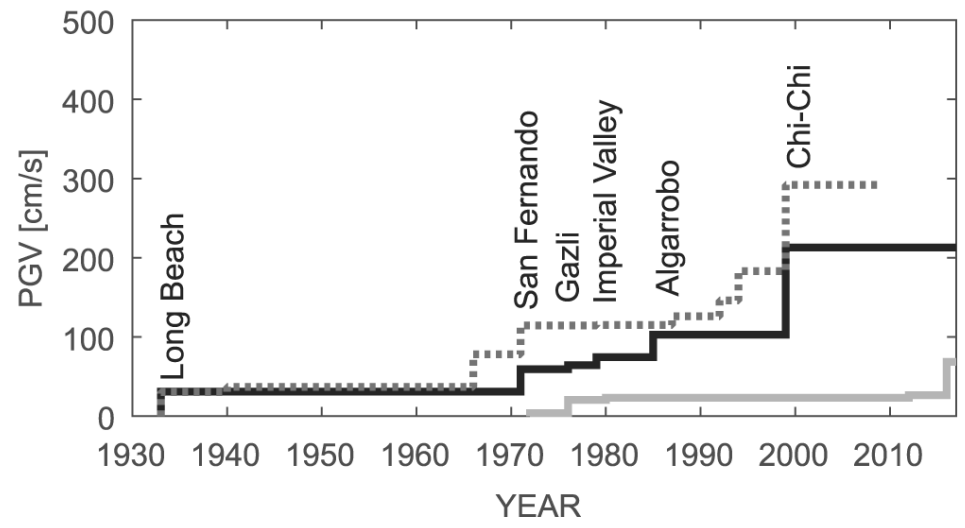

(b)

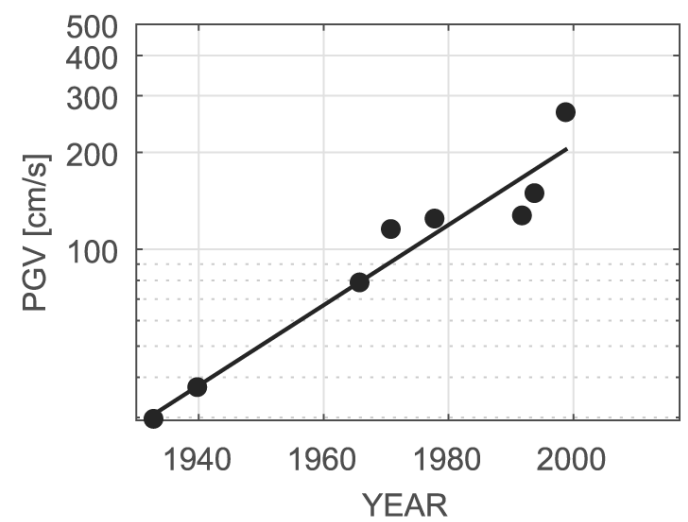

(d)

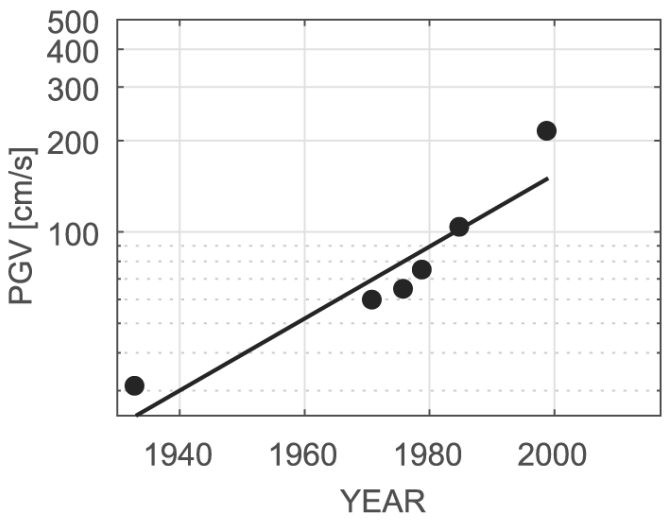

Figure 2. Largest recorded values of PGV, (a) horizontal; (b) worldwide horizontal in logarithmic scale; (c) vertical; (d) worldwide vertical in logarithmic scale.

California $(0.59 \mathrm{~m} / \mathrm{s}$ at Pacoima dam), the 1976 Gazli, Uzbekistan $(0.64 \mathrm{~m} / \mathrm{s}$, at Karakyr), the 1979 Imperial Valley, California $(0.74 \mathrm{~m} / \mathrm{s}$ at El Centro Differential Array), the 1985 Algarrobo, Chile (1.03m/s at Valparaíso), and the 1999 Chi-Chi earthquake, Taiwan $(2.13 \mathrm{~m} / \mathrm{s}$ at Taichung, TCU068). Overall, the study showed no increase of maximum values in the current decade. See Table 4 for detailed ground motion information.

\section{Discussion}

\subsection{Data increase}

It is noted that maximum PGA and PGV values recorded so far qualitatively align if plotted in logarithmic scale versus time. This is shown in Figure $1 \mathrm{~b}, \mathrm{~d}$ and Figure $2 \mathrm{~b}, \mathrm{~d}$, where the recorded maxima are shown in logarithmic scale. These trends can be associated to the rapid increase of the archived strong motion records in

\footnotetext{
${ }^{4}$ The plots were obtained examining the flat-files or counting the waveforms returned by search engines of the web-portals of the databases. Note that, because COSMOS and NOAA databases return individual components, the annual growth was approximately computed dividing by three the number of all archived waveforms.
}

the databases, which is illustrated in Figure 3, where the cumulative number of three-component accelerograms is plotted for each of the examined databases. ${ }^{4}$ It can be seen that the amount of data has been rapidly increasing especially in the last decades.

\subsection{Italy vs world}

The global and Italian trends of maximum recorded IMs are compared in Figure 1a,c and 2a,c. The Italian values, as expected because of the features of the regional seismicity and the period for which instrumental data are available, are significantly smaller and have increased at a slower pace.

\section{Final remarks}

The presented study attempted to examine the maximum values of peak ground motion parameters (i.e., PGA and PGV) ever recorded in Italy. For comparison, starting from relevant literature on the topic, the study also tried to recompile and update the worldwide trend via the analysis of a number of national and international strong motion databases. The notable remarks are listed as follows.

1. The largest recorded intensity values in Italy were 


\begin{tabular}{|c|c|c|c|c|c|c|c|}
\hline Year & Event & Station (Soil class $\left.{ }^{\dagger}\right)$ & Focal Mechanism & $\begin{array}{l}\text { Magnitude } \\
\operatorname{Mw}\left(M_{L}\right)\end{array}$ & $\begin{array}{l}\text { Distance }^{* 1} \\
{[\mathrm{~km}]}\end{array}$ & $\mathrm{PGV}[\mathrm{cm} / \mathrm{s}]$ & Source \\
\hline \multicolumn{8}{|c|}{ Horizontal } \\
\hline 1933 & Long Beach & $\begin{array}{l}\text { Public Utilities Bldg., } \\
\text { CA (-) }\end{array}$ & Strike-slip & 6.4 & 0.8 & 29.4 & {$[\mathrm{C}]$} \\
\hline 1940 & El Centro & $\begin{array}{c}\text { El Centro, Array \#9, } \\
\text { CA (D) }\end{array}$ & Strike-slip & 6.9 & $12.2^{* 3}$ & 36.9 & {$[\mathrm{C}]$} \\
\hline 1966 & Parkfield & Cholame 2WA, CA (E) & Strike-slip & 6.1 & 3.5 & 78.1 & {$[\mathrm{C}]$} \\
\hline 1971 & San Fernando & Pacoima Dam, CA (A) & Thrust & 6.6 & 1.8 & 114.4 & {$[\mathrm{P}]$} \\
\hline 1978 & Tabas & Tabas, Iran (B) & Thrust & 7.4 & 2.1 & 123.3 & {$[\mathrm{P}]$} \\
\hline 1992 & $\begin{array}{c}\text { Cape } \\
\text { Mendocino }\end{array}$ & $\begin{array}{l}\text { Cape Mendocino, CA } \\
\text { (C) }\end{array}$ & Thrust & 7.0 & $15.5^{* 3}$ & 126.1 & {$[\mathrm{C}]$} \\
\hline 1994 & Northridge & $\begin{array}{l}\text { Rinaldi Receiving Sta., } \\
\text { CA, (D) }\end{array}$ & Thrust & 6.7 & 6.5 & 147.9 & {$[\mathrm{P}]$} \\
\hline 1999 & Chi-Chi & Taichung, Taiwan (C) & Thrust oblique & 7.6 & 0.3 & 264.0 & {$[\mathrm{P}]$} \\
\hline \multicolumn{8}{|c|}{ Vertical } \\
\hline 1933 & Long Beach & $\begin{array}{l}\text { Public Utilities Bldg., } \\
\text { CA (-) }\end{array}$ & Strike-slip & $\$ 1$ & $0^{* 2}$ & 30.8 & {$[N]$} \\
\hline 1971 & San Fernando & Pacoima Dam, CA, (A) & Thrust & 6.6 & 1.8 & 59.2 & {$[\mathrm{P}]$} \\
\hline 1976 & Gazli & $\begin{array}{l}\text { Karakyr, Uzbekistan } \\
\text { (D) }\end{array}$ & Thrust & 6.7 & $12.8^{* 2}$ & 64.3 & {$[\mathrm{~S}]$} \\
\hline 1979 & $\begin{array}{l}\text { Imperial } \\
\text { Valley }\end{array}$ & $\begin{array}{l}\text { Differential Array, CA } \\
\text { (D) }\end{array}$ & Strike-slip & 6.5 & 5.6 & 74.4 & {$[\mathrm{C}]$} \\
\hline 1985 & Algarrobo & $\begin{array}{l}\text { Valparaíso, VARP08R, } \\
\text { Chile (D) }\end{array}$ & Megathrust & 7.9 & $46.8^{* 2}$ & 102.8 & {$[\mathrm{CS}]$} \\
\hline 1999 & Chi-Chi & Taichung, Taiwan (C) & Thrust oblique & 7.6 & 0.3 & 213.0 & {$[\mathrm{P}]$} \\
\hline
\end{tabular}

Table 4. Records determining the compiled PGV history worldwide.

$\dagger$ NEHRP soil classification [BSSC 1994], (-) denotes unknown soil conditions.

$\$ 1$ Unknown magnitude, ${ }^{*}{ }^{*}$ Closest distance, ${ }^{{ }^{*} 2}$ Epicentral distance, ${ }^{*} 3$ Hypocentral distance.

$[\mathrm{C}]=$ COSMOS, $[\mathrm{P}]=$ PEER NGA, $[\mathrm{N}]=$ NOAA, $[\mathrm{S}]=$ SIMBAD, $[\mathrm{CS}]=$ CSGMF.

recently updated, by the 2016 central Italy earthquakes, to PGA values of about $0.9 \mathrm{~g}$ (both horizontal and vertical) and to PGV values of about $0.8 \mathrm{~m} / \mathrm{s}$ and $0.7 \mathrm{~m} / \mathrm{s}$ (horizontal and vertical, respectively).

2. The records from the recent earthquakes in Japan, the 2008 Iwate-Miyagi and the 2011 Tohoku earthquakes, currently hold the worldwide largest PGA values, about $4 \mathrm{~g}$ (vertical) and $3 \mathrm{~g}$ (horizontal), respectively (although there is discussion about some of these values); the PGV current maxima are larger than $2.0 \mathrm{~m} / \mathrm{s}$ (horizontal and vertical), both from the 1999 Chi-Chi earthquake.

3.The global trend of peak IMs corresponds to a rapid growth of strong motion data available. Moreover, the maximum values of PGA and PGV recorded worldwide so far qualitatively align when plotted in logarithmic scale versus time.

The obtained trend can provide reference values for further observations or for hazard assessment studies, which often need to extrapolate towards large return periods and intensities. However, it is to remark that the generality of the results may be limited by the data available to the authors and the simplified search in some databases.

\section{Data and sharing resources}

The following strong-motion databases were considered as data sources for this study (all last accessed on Feb. 2017): COSMOS Virtual Data Center [http://www.strongmotioncenter.org/vdc]; PEER Ground Motion Database NGA West 2 [http:// ngawest2.berkeley.edu]; ESM [http:/ / esm.mi.ingv.it]; SIMBAD (ReLUIS), NOAA [https://www.ngdc.noaa. gov/]; K-NET\&KiK-net (NIED, Japan) [http:/ / www. kyoshin.bosai.go.jp]; JMA (Japan) [http://www.jma. go.jp]; Harbor area strong motion network (PARI, Japan) [http://www.eq.pari.go.jp/kyosin/]; GeoNet (Earthquake Commission and GNS Science, New Zealand) [http://www.geonet.org.nz]; CSGMF (Chile) [https: / / nees.org]; ITACA (INGV, Italy) [http: / / itaca. mi.ingv.it/]; MSMD (Mexico) [CD-ROM] (Instituto de Ingeniería, UNAM; Comisión Federal de Electricidad; Centro de Investigacíon Científica y de Educación Superior de Ensenada; Fundación ICA; Centro de Instrumentación y Registro Sísmico; Centro Nacional 


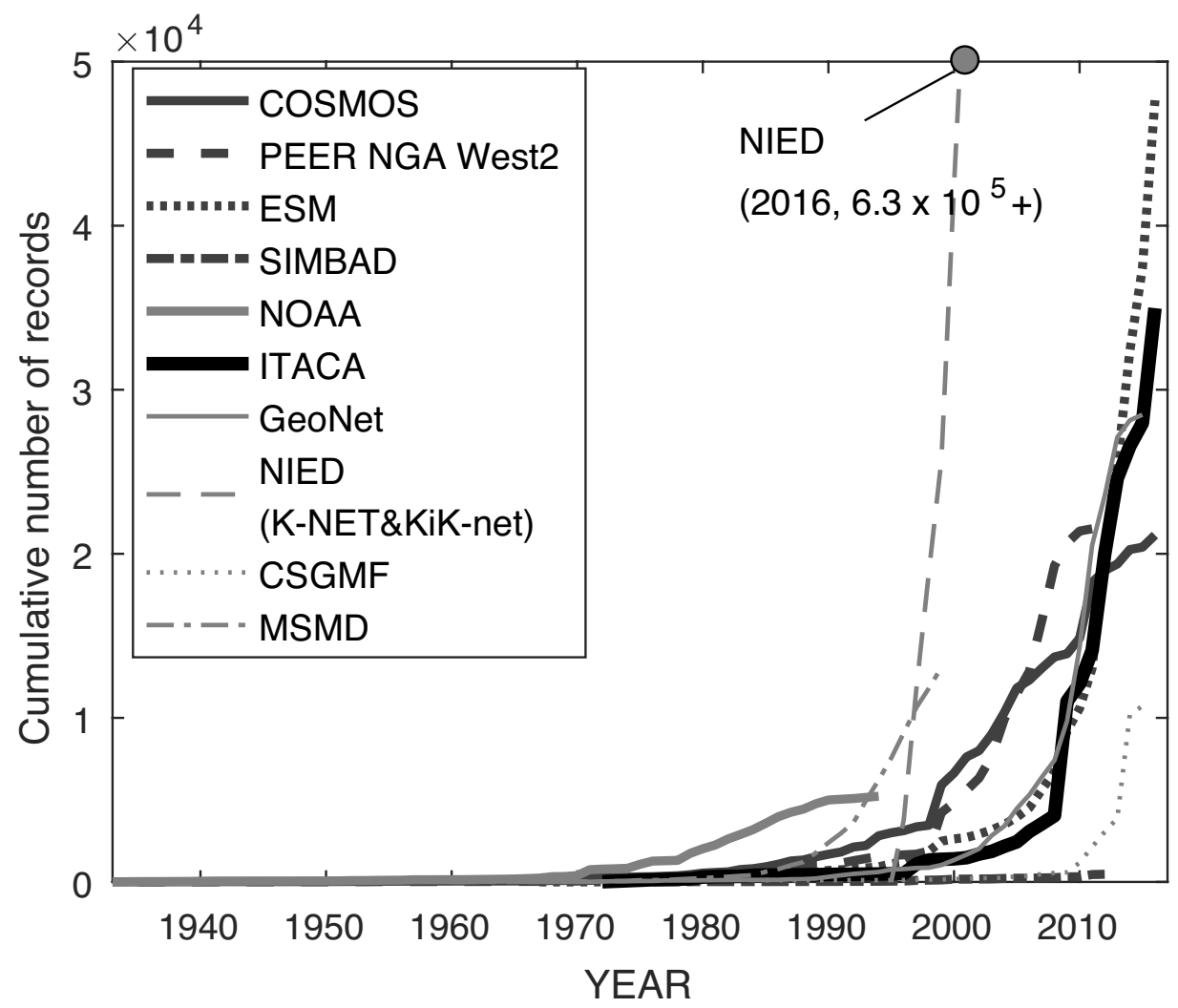

Figure 3. The annual increase of the strong motion records archived in databases (processed and unprocessed data).

de Prevención de Desastres; Universidad Autónoma Metropolitana, campus Azcapotzalco; Instituto de Geofísica; and La Sociedad Mexicana de Ingeniería Sísmica, Mexico); and Red Acelerográfica del IINGEN de la UNAM [http:/ / aplicaciones.iingen.unam. $\mathrm{mx} /$ AcelerogramasRSM/] (Instituto de Ingeniería, UNAM, Mexico).

Acknowledgements. The study presented in this paper was developed within the activities of ReLUIS (Rete dei Laboratori Universitari di Ingegneria Sismica) for the project ReLUIS-DPC 20142018. Data from dr. Lucia Luzi (Istituto Nazionale di Geofisica e Vulcanologia, Italy) and prof. Eden Bojorquéz (Universidad Autonoma de Sinaloa, Mexico) are gratefully acknowledged.

\section{References}

Alavijeh H. M. and E. Farzanegan (2003). Iran strong motion network. Asian J. Civ. Eng. (Build. and Hous.), 4(2-4): 173-186.

Alcántara L. and C. Pérez (2004). Record processing methods and procedures for the Mexican strong motion program, Invited Workshop on Archiving and Web Dissemination of Geotechnical Data, COSMOS.

Alcántara L., R. Quaas, C. Pérez, M. Ayala, M. A. Macías, H. Sandoval, E. Mena, E. Andrade, F. González, E. Rodriguez, E. Vidal, L. Murguía, M. Luna, J. M. Espinoza, A. Cuellar, L. Camarillo, S.
Ramos, M. Sánchez, E. Guevara, J. A. Flores, B. Lopéz, R. Ruiz, J. Pacheco, M. Ramírez, J. Aguilar, J. Juárez, R. Vera, A. Gama, R. Cruz, F. Hurtado, R. Martín del Campo and F. Vera (2000). Mexican Strong Motion Database. CD-ROM v2, Mex. Soc. of Seis. Engrg.

Ambraseys N., P. Smit, J. Douglas, B. Margaris, R. Sigbjörnsson, S. Ólafsson, P. Suhadolc and G. Costa (2004). Internet-site for European strong-motion data. Boll. Geofis. Teor. Appl., 45(3): 113-129.

Ancheta T. D., R. B. Darragh, J. P. Stewart, E. Seyhan, W. J. Silva, B. S. J. Chiou, K. E. Wooddell, R. W. Graves, A. R. Kottke, D. M . Boore, T. Kishida and J. L. Donahue (2014). NGA-West2 database. Earthq. Spectra, 30(3): 989-1005.

Aoi S., T. Kunugi and H. Fujiwara (2004). Strong motion seismograph network operated by NIED: K-NET and KiK-net. J. Jpn. Assoc. Earthq. Eng., 4(3): 65-74.

Archuleta R., J. Steidl and M. Squibb (2005). The cosmos virtual data center. In Directions in Strong Motion Instrumentation, 209-222. Springer Netherlands.

Bastías N. and G. A. Montalva (2016). Chile Strong Ground Motion Flatfile. Earthq. Spectra, 32(4): 2549-2566.

BSSC (1994). NEHRP recommended provisions for 
seismic regulations for new buildings, Part 1-Provisions, FEMA 222A, Federal Emergency Management Agency.

Bommer J. and A. Martínez-Pereira (2000). Strong motion parameters: definition, usefulness and predictability. In Proc. of 12th World Conference on Earthquake Engineering, Auckland, 3(2): 127-172.

Boore D. M. (2010). Orientation-independent, nongeometric-mean measures of seismic intensity from two horizontal components of motion. Bull. Seismol. Soc. Am., 100(4): 1830-1835.

Bungum H., E. S. Husebye and F. Ringdal (1971). The NORSAR array and preliminary results of data analysis. Geophys. J. Int., 25(1-3): 115-126.

Çelebi M., S. Toprak and T. Holzer (2000). Strong-motion, site-effects and hazard issues in rebuilding Turkey: in light of the 17 August 1999 earthquake and its aftershocks. Int. J. Hous. Sci. Appl, 24: 21-38.

CEN, European Committee for Standardisation TC250/SC8/ (2003). Eurocode 8: Design Provisions for Earthquake Resistance of Structures, Part 1.1: General rules, seismic actions and rules for buildings, PrEN1998-1.

Dan K. (1995). Simulation of soil and structure interaction observed in the earthquake motions at the Kushiro District Meteorological Observatory. J. Struct. Constr. Eng., AIJ, 470: 75-84 (in Japanese).

Darragh R., T. Cao, C. Cramer, M. Huang and A. Shakal (1992). Processed CSMIP strong motion data from the Cape Mendocino/Petrolia earthquake of April 25, 1992: Release No. 1. Calif. Div. Mines and Geology, Office of Strong Motion Studies, Report No. OSMS, 92-12.

De Luca F., E. Chioccarelli and I. Iervolino (2011). Preliminary study of the 2011 Japan earthquake ground motion record V1.01, available at http:// www.reluis.it.

Fäh D., D. Giardini, P. Kästli, N. Deichmann, M. Gisler, G. Schwarz-Zanetti, S. Alvarez-Rubio, S. Sellami, B. Edwards, B. Allmann and F. Bethmann (2011). ECOS-09 earthquake catalogue of Switzerland release 2011 report and database. Public catalogue, 17. 4. 2011. Swiss Seismological Service ETH Zurich. RISK.

Goto H. and H. Morikawa (2012). Ground motion characteristics during the 2011 off the Pacific coast of Tohoku earthquake. Soils and Foundations, 52(5): 769-779.

Haddadi H., A. Shakal, C. Stephens, W. Savage, M. Huang, W. Leith and J. Parrish (2008). Center for Engineering Strong motion Data (CESMD). In
Proc. of the 14th World Conference on Earthquake Engineering.

Iwan W. D. and X. Chen (1994). Important near-field ground motion data from the Landers earthquake. In Proc. of the 10th European Conference on Earthquake Engineering.

Japanese Meteorological Agency. (2004). Natural disaster emergency report Vol. 7. http://www. jma.go.jp/jma / kishou/books / saigaiji / saigaiji_200407.pdf (last accessed on February 2017).

Japan Society of Civil Engineering and Japanese Geotechnical Society (2003). Joint meeting report on the 2003 Northern Miyagi earthquake in Japan. https://www.jsce.or.jp/report/23/report20030726.pdf (in Japanese, last accessed on February 2017).

Kaiser A., C. Van Houtte, N. Perrin, L. Wotherspoon and G. McVerry (2017). Site characterisation of GeoNet stations for the New Zealand strong motion database. Bull. NZ Soc. Earthquake Eng., 50(1): 39-49.

Luzi L, F. Pacor and R. Paolucci (2016a). Italian Accelerometric Archive v 2.1. Istituto Nazionale di Geofisica e Vulcanologia, Dipartimento della Protezione Civile Nazionale. doi: 10.13127/ITA$\mathrm{CA} / 2.1$.

Luzi L, R. Puglia, E. Russo and ORFEUS WG5 (2016b). Engineering Strong Motion Database, version 1.0. Istituto Nazionale di Geofisica e Vulcanologia, Observatories \& Research Facilities for European Seismology. doi: 10.13127/ESM.

Motosaka M. (2012). Lessons of the 2011 great east Japan earthquake focused on characteristics of ground motions and building damage. In Proc. of the International Symposium on Engineering Lessons Learned from the 2011 Great East Japan Earthquake, 166-185.

Munguia L., J. G. Anderson and J. A. Brune (1988). The Cerro Prieto, Baja California Earthquake of February 6, 1987 and processed strong motion data. California Department of Conservation Division of Mines and Geology office of Strong Motion Studies Report OSMS 87-04.

Nagashima F., H. Kawase, S. Matsushima, F. J. Sánchez-Sesma, T. Hayakawa, T. Satoh and M. Oshima (2012). Application of the H/V spectral ratios for earthquake ground motions and microtremors at K-NET sites in Tohoku region, Japan to delineate soil nonlinearity. In Proc. of the 15th World Conference of Earthquake Engineering.

North R. G. (1994). The Canadian national seismo- 
graph network. Ann. of Geophys-Italy, 37(5).

ReLUIS-INGV Workgroup (2016). Preliminary study on strong motion data of the 2016 central Italy seismic sequence V6, available at http://www. reluis.it (last accessed on February 2017).

Quaas R., S. Medina, L. Alcántara, E. Mena, J. Espinosa, J. Otero, C. Javier, O. Contreras and L. Munguia (1996). Mexican strong motion database. An integrated system to compile accelerograph data from the past 35 years. In Proc. 11th World Conference on Earthquake Engineering, Paper (No. 1804).

Shakal A., R. Sherburne and D. Parke (1984). CDMG strong motion records from the Morgan Hill, California, earthquake of 24 April 1984. California Dept. of Conservation, Division of Mines and Geology, Office of Strong Motion Studies.

Smerzini C., C. Galasso, I. Iervolino and R. Paolucci (2014). Ground motion record selection based on broadband spectral compatibility. Earthq. Spectra, 30(4): 1427-1448.

Smerzini C. and R. Paolucci (2013). Research Project DPC - RELUIS 2010-2013, SIMBAD: a database with selected input motions for displacement-based assessment and design - 3rd release, available at http:/ / wpage.unina.it/iuniervo/SIMBAD_Database_Polimi.pdf (last accessed on February 2017).

Strasser F. and J. Bommer (2009a). Large-amplitude ground-motion recordings and their interpretations. Soil Dyn. Earthq. Eng., 29(10): 1305-1329.

Strasser F. and J. Bommer (2009b). Review: strong ground motions - Have we seen the worst?. Bull. Seismol. Soc. Am., 99(5): 2613-2637.

Van Houtte C., S. Bannister, C. Holden, S. Bourguignon and G. McVerry (2017). The New Zealand Strong Motion Database, Bull. NZ Soc. Earthquake Eng., 59(1):1-20.

Wang G., X. Zhou, P. Zhang and H. Igel (2002). Characteristics of amplitude and duration for near fault strong ground motion from the 1999 ChiChi, Taiwan earthquake. Soil Dyn. Earthq. Eng., 22(1): 73-96.

Yamada M., A. H. Olsen and T. H. Heaton (2009). Statistical features of short-period and long-period near-source ground motions. Bull. Seismol. Soc. Am., 99(6): 3264-3274.

\footnotetext{
${ }^{*}$ Corresponding author: Iunio Iervolino, Dipartimento di Strutture per l'Ingegneria e l'Architettura, Università degli Studi di Napoli Federico II, Naples, Italy; email: iunio.iervolino@unina.it.
}

2017 by Istituto Nazionale di Geofisica e Vulcanologia. All rights reserved 